\title{
磁性アタッチメントを応用した可撤性ブリッジ
}

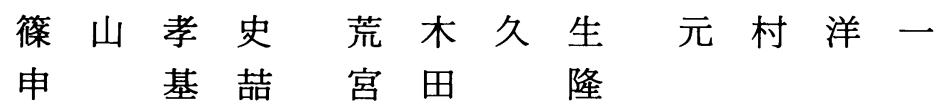

\section{Magnetic Attachment Applied to Removable Bridge}

\author{
Takafumi Shinoyama Hisao Araki Youichi Motomura \\ Kitetsu Shin and Takashi Miyata
}

Recently, superior magnetic attachment has been developed and put to clinical use. In particular, the effectiveness is anticipated for spical bad teeth because lateral force is hard to act on maintenance teeth as for the magnetic attachment. When a condition of the abutment tooth is compar atively good, we reduce unrest of the denture by giving a supporting system and can utilize it positively. And, there is not function fall by abration. As for application of magnetic attachment which is used for a healthy teeth and spical bad teeth, it is thought when effective. Magnetic attachment has functionality which became stable, esthetics excelled.

In this study, we report it about a clinical case of removable bridge that magnetic attachment was applied as retainer.

\section{緒言}

近年，小型で強力な吸引力を有し耐蝕性にも優 れた磁性ステンレスが開発され, 磁性アタッチメ ントが臨床応用されることが多くなってき $た^{1 \sim 4)}$. 特に, 磁性アタッチメントは側方力が維持 雪に作用しにくいため, 骨植不良歯に対してその 有効性が期待されているが, 義歯の機能性の面で は支台歯の負担の軽減を重視している 固たる抵抗源がないと動摇の大きいものとなって しまう.そこで，支台歯の条件が比較的良好な場 合, 補助的な機構を付与することで義歯の動摇を 軽減し, 磁性アタッチメントを積極的に利用する ことが可能となる.そして数あるアタッチメント のなかで維持力が数值化でき, しかも磨耗による 機能低下がなく, 健全歯と予後不良歯に対して使

明海大学菌学部菌科臨床研究所
い分けができるため, 磁性アタッチメントを応用 することは有効であると思われる。そこで今回, 上顎右側欠損部に磁性アタッチメントを維持装置 として応用した可撤性ブリッジによる補経を行っ たので報告する。

\section{症例}

患 者: 49 歳, 女性.

初診日：1996 年 1 月 13 日.

主 訴：右上のさし歯がとれた。

既往歴：特記すべき事項なし。

現病歴： 2 年程前に作製した 3 の陶材焼付け鋳 造冠がコアーごと脱離したため本診療所に来院.

現 症:

口腔内所見 ; 初診時, (6) 5 (4)の固定性ブリッジ が装着されており(図 1，2），7忺損し放置さ れていた．3山は鋳造冠がコアごと脱離していた。 なお, 口腔清掃状態は良好であった。 
表 1 歯周組織診査

\begin{tabular}{|c|c|c|c|c|c|c|}
\hline 調査項目 & 部位 & 6 & 4 & 3 & $\underline{2}$ & 1 \\
\hline プロービング & $\mathrm{B}$ & 211 & 222 & 324 & 323 & 323 \\
\hline デプス (mm) & $\mathrm{P}$ & 222 & 333 & 333 & 333 & 323 \\
\hline \multicolumn{2}{|l|}{ 歯の動摇（度） } & 0 & 1 & 1 & 1 & 1 \\
\hline \multicolumn{2}{|c|}{ プロービング時の出血 } & - & - & - & - & - \\
\hline
\end{tabular}

歯周組織診査；上顎右側欠損部を中心とした歯 周組織診査を行った。その結果(表 1)， 4321 には 1 度の動摇が, そして 3 には最大 $4 \mathrm{~mm}$ の歯 周ポケット深さが認められた。

X線所見； 43 には歯根の不完全破折様透過像 が，そして，2根尖病巣様透過像が認められ た(図 3 ).

診 断：以上の診查結果から，1） 5! : 欠損,

2） 2 根尖性歯周炎，3） 43 : 歯根破折, と診 断した。

治療方針：支台歯となるべき $62 \mid$ の骨植が良好 のため, 磁性アタッチメント(図 4 ) を用いたコー ヌスタイプの可撒性ブリッジを応用することに し， 4 には通常の根面板，3にはキーパーを可及 的に低く設定した根面板を合着し, 垂直方向の最 小限の維待のみを得ることにした。 また，義歯の 煩舌的ローテーションを防止するため $1 \mid$ の口蓋側 にブレイジングアームを設けることにした。

治療経過：暫間義歯を装着して審美, 発音, 咀 嚼などに対する反応をみながら義歯を修正した (図 5 ).62|の内冠のワックスアップはハウジン グパターンを組み込んだ形態で蠟型を完成させ, 3は通常の根面板に準じた蠟型上面にキーパーを 設置し鋳造後（図6)，支台歯に合着した（図 7 )。 次にレジンコーピングを用いて印象採得し，その 作業模型上で外冠のワックスアップを作製し鋳造 した.

また，人工歯排列の前準備として磁石構造体を 完成義歯内に取り付ける際, チェアータイムを短 くし, かつ, 均一なレジンの厚みを確保するため に磁石構造体より一回り大きい石膏ダミーを作製 し作業模型の根面板上に接着, 固定し, 外冠完成

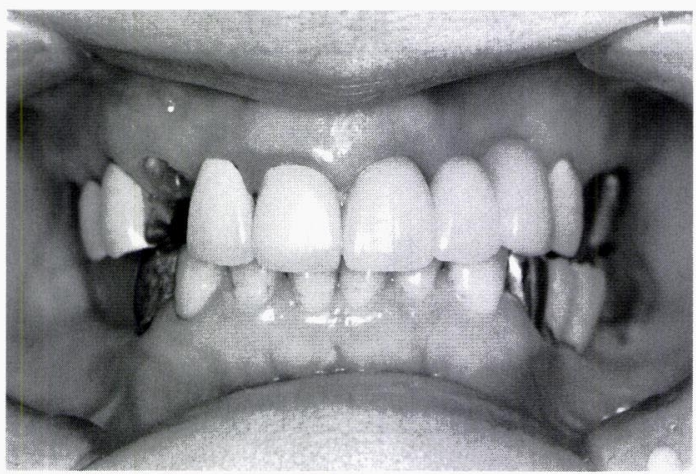

図 1 初診時正面観
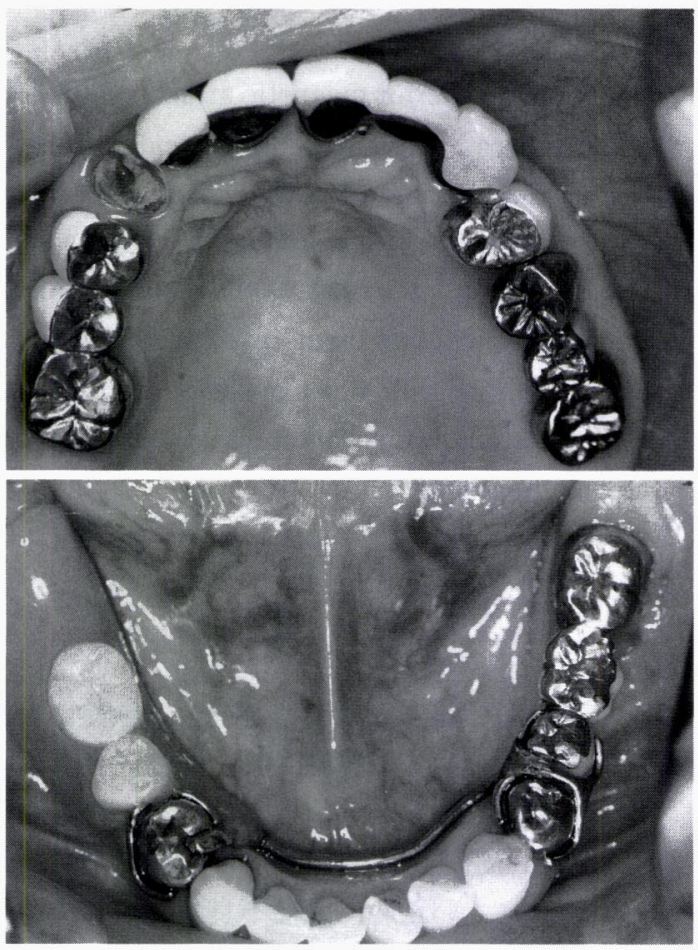

図 2 初診時上下顎咬合面観

後(図 $8 \sim 10$ ), 口腔内で磁石構造体を接着性レジ ンにて合着した（図 11).

可撤性ブリッジ装着後(図 12,13 ), 歯周組織の 炎症, 支台歯の疼痛, 動摇は認められなかった。 義歯の維持力の低下はなく，装着感も良好で，患 者は咀嚼に不自由を感じることなく良好な経過を たどっている．また，義歯の着脱に不自由するこ 


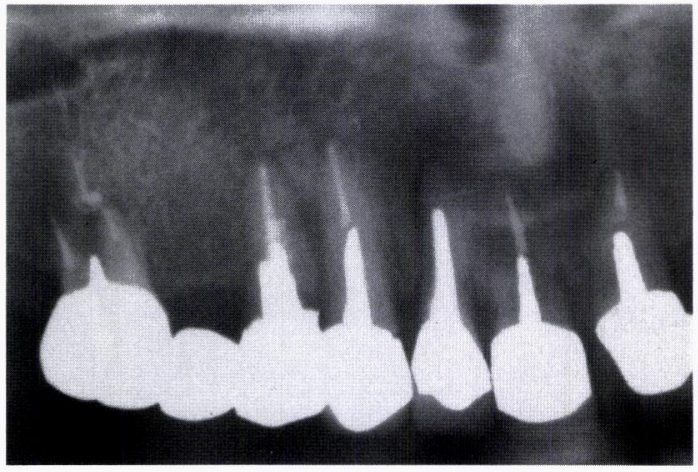

図 3 初診時オルソパントモX線写真

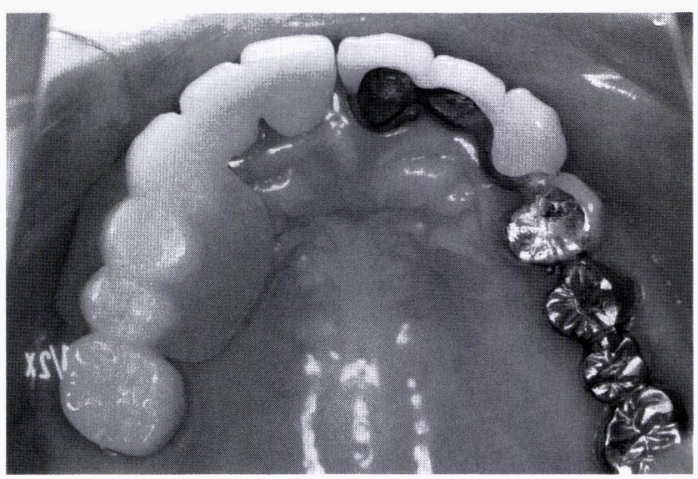

図 5 治療用義歯装着

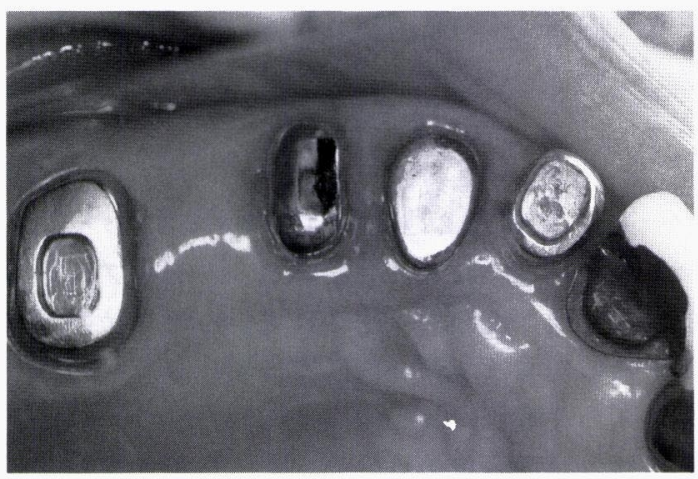

図 7 支台歯に合着された根面板（内冠）

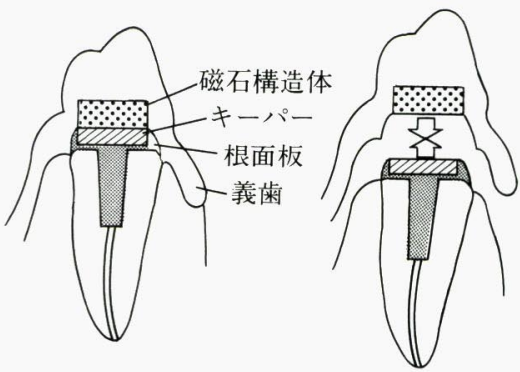

図 4 磁性アタッチメントの構造

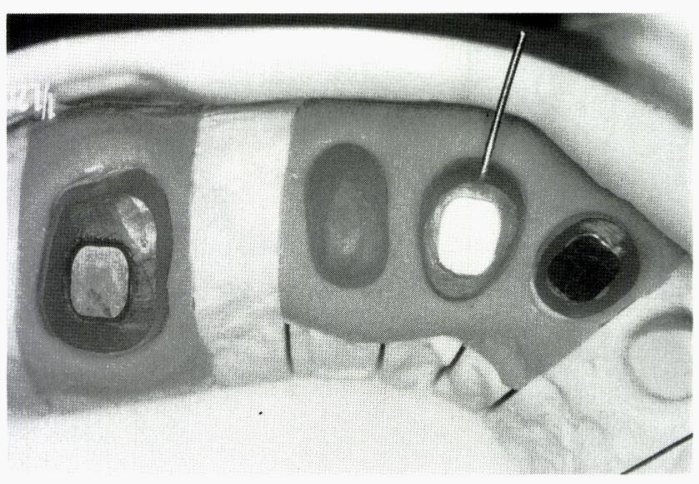

図 6 根面板（内冠）の蠟型採得

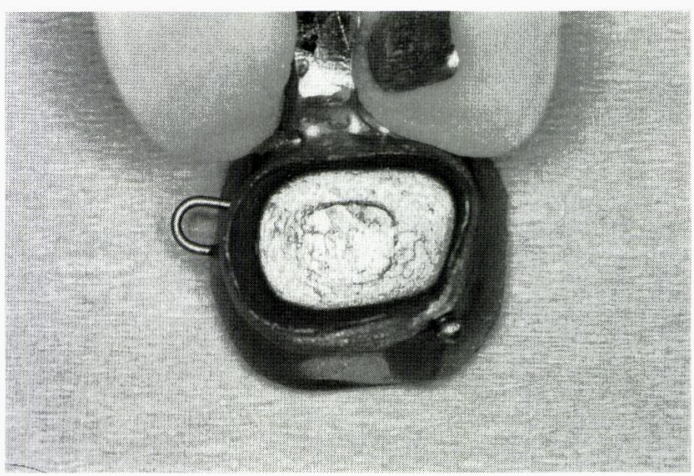

図 8 キーパーを外冠内面に鋳接 


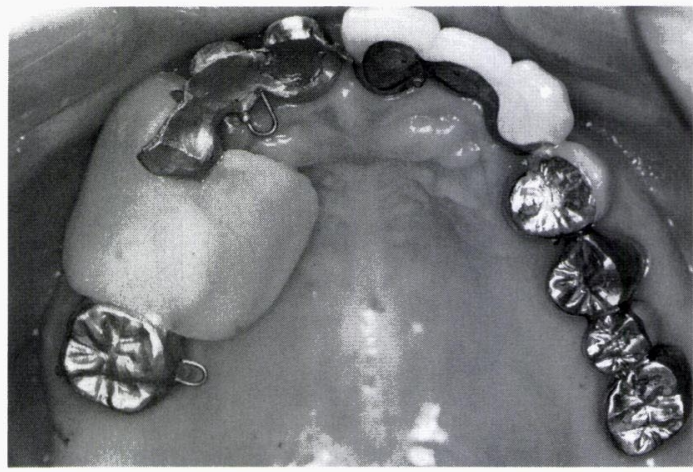

図 9 外冠試適

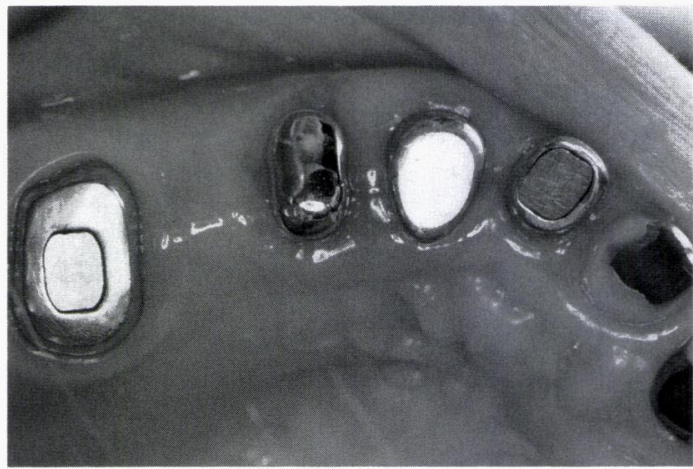

図 11 磁石構造体の合着された内冠

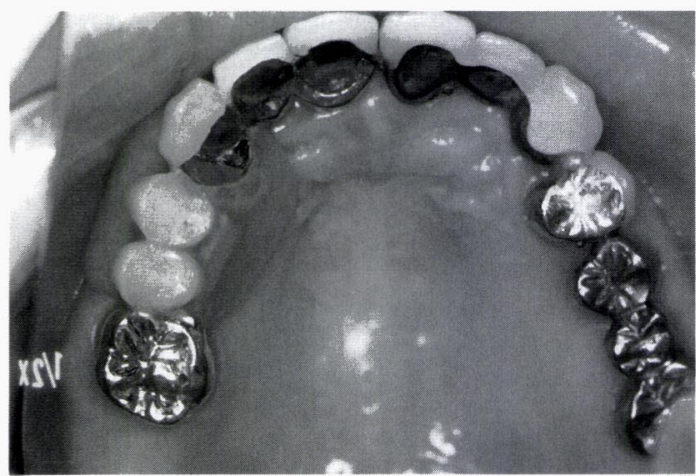

図 13 口腔内に装着された完成義歯咬合面観

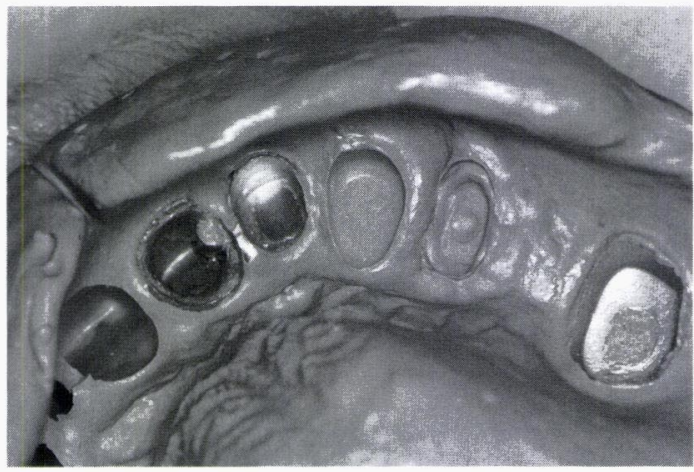

図 10 外冠を組み込んだ歯列印象

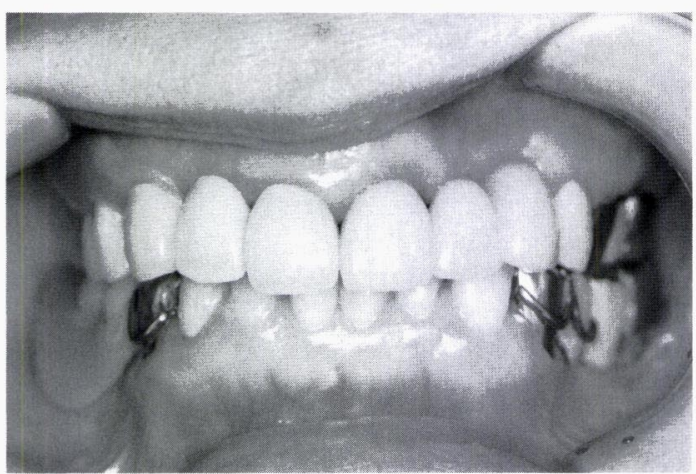

図 12 口腔内に装着された完成義歯正面観

となく内面は十分に清掃されていた.

\section{ま と め}

一般に欠損補緅処置を行う場合, コーヌスク ローネに代表されるようなリジットタイプのもの がかなり広く臨床に多用されている ${ }^{5)}$.しかし, 技 工操作の煩雑さや高い精度の必要性ならびに術者 が意図した維持力を得ることは他の維持装置に比 べて難しい場合がある。そこで，長期的な利用に おいても維持力の低下がなく，コーヌス角や内冠 の高さの設定が自由で支台歯として利用法のない 残根への応用が可能な磁性アタッチメントを用い た。可撤性ブリッジの支台装置として磁性アタッ チメントを応用することにより支台歯の選択範囲 
が広がり，その結果，設計の自由度が高まり無理 な設計を回避することができ, 良好な予後が期待 された。このことから, 磁性アタッチメントを欠 損補綴に積極的に応用することは, 非常に有用で あると思われる。

\section{参考文献}

1）田中貴信：磁性アタッチメント一磁石を利用し た新しい補経治療一. 医歯薬出版(東京), 1993, 86 93, 138 139.

2）田中貴信：マグフィットシステム。デンタルダ イヤモンド社 (東京)，1995，21〜37.
3）石幡伸雄，水谷 紘，藍 稔：磁性合金の補 経領域における応用一第 5 報一磁性アタッチメ ントとその骨植不良歯への応用. 補緅誌 31 ： 1445-1453， 1987.

4) Brewer, A. A. and Morrow, R. M. : Overdentures. Mosby. (St. Louis), 1975, 376 397.

5）Korber, K. H. : 田端恒雄, 河野正司, 福島俊士 共訳：ケルバーの補緅学第 2 巻, クインテッセ ンス出版, 1982, 144-191.

別刷請求先：荒木久生

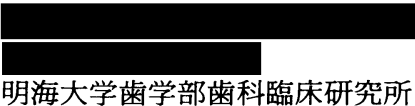

